Elsevier Scientific Publishing Company, Amsterdam - Printed in The Netherlands

\title{
FROM KILLER WEED TO DROP-OUT DRUG: THE CHANGING IDEOLOGY OF MARIHUANA
}

\author{
JEROME L. HIMMELSTEIN
}

A major change occurred in the dangers attributed to marihuana use in the mid-1960s in the United States: What had once been regarded as a "Killer Weed" became seen as a "Drop-out Drug." Lost amid the loud debates over the legality and morality of marihuana use, this change has rarely been noticed or studied; nonetheless, it is important, for it involves a major shift in how the public discussion of marihuana was framed - a shift that was symptomatic of other important social changes of the time.

From the 1930s to the mid-1960s, marihuana was primarily characterized as a "Killer Weed," a drug that made its users violent, criminal, and aggressive. Writing shortly after the passage of the Marihuana Tax Act of 1937, anti-drug crusaders Earle and Robert Rowell put it this way: "While opium kills ambition and deadens initiative, marihuana incites to immorality and crime" [1].

In the turbulent debate over marihuana beginning in the 1960s, the Killer Weed claim was abruptly replaced by the virtually opposite assertion that marihuana induced passivity and destroyed motivation. What the Rowells had once said about opium in the 1930s in contrast to marihuana now was said about marihuana itself: it killed ambition and deadened initiative; it created an "amotivational syndrome"; it was a "Drop-out Drug." Thus, in summarizing the drug's effects, Time Magazine argued in 1965 that marihuana "affects users' judgment and if used daily will dull a student's initiative"; and Benjamin Spock, the pediatrician and political activist, noted that "a small percentage of users, the 'potheads,' make its frequent use the focus of their existence and lose some of their ambition and aim" [2] .

The shift from Killer Weed to Drop-out Drug involved a change not only in the specific dangers attributed to marihuana use but also (and more importantly) in the general image of the drug and its users. It thus entails nothing less than a transformation of the assumptions underlying public discussion of marihuana.

In what follows, I shall document and explain this radical shift in the image of marihuana. I shall show that a Killer Weed image came to dominate

The University of Michigan, Ann Arbor, Michigan 48104, USA 
and frame discussion of marihuana in the mid-1930s and that this image was replaced by that of a Drop-out Drug in the 1960s. I shall also argue that the transformation of Killer Weed to Drop-out Drug resulted from changes in three crucial social factors - the array of organized political actors in the drug-control arena, the perceived social background of marihuana users, and the symbolic meaning of the drug. In doing so, I shall draw upon three important guiding concepts in recent drug control literature: What I shall call "entrepreneurship," "social locus," and "symbolic politics."

The present study is thus concerned with ideology in the broadest sense: ideas considered in the context of social action. It seeks to identify the socially dominant conceptual frameworks within which marihuana was discussed at various times and to determine the social structural factors that shaped these frameworks. It examines the kinds of dangers imputed to marihuana and the extent to which these imputed dangers provided a basis for an overall image of drug and user.

Previous sociological and historical work, in contrast, has focused primarily on changes in marihuana laws, especially the passage of the Marihuana Tax Act in 1937 and the debate over law reform in the late 1960s and the 1970s [3]. Although this work has also been concerned with changing assessments of how dangerous marihuana is, it has paid considerably less attention to the specific dangers attributed to marihuana or the general image of the drug. When these have received attention, it has been for debunking, not understanding. Bonnie and Whitebread are virtually alone in noting the prevalence of the violence claim in earlier discussions of marihuana and the shift to an emphasis on "psychological dependence, amotivation, and alienation" in the 1960s [4].

This study of marihuana ideology also seeks to make several basic points about ideology in general. First, it is structured and selective; that is, it is organized into "persistent patterns of cognition, interpretation, and presentation, of selection, emphasis, and exclusion" [5]. We shall see that the ideology of marihuana at any given time was not a haphazard collection of observations and beliefs but was organized around a coherent set of assumptions about the drug and its users.

Second, the cognitive framework of ideology is socially determined; that is, the specific ways in which ideology is structured or framed in turn are shaped by or fit with other important features of social structure. We shall see that the images of marihuana that structure the discussion of the drug at any specific time were themselves social constructions.

Finally, explaining a set of publicly accepted beliefs sociologically does not necessarily mean explaining them away or proving them false. What a sociological account implies, instead, is that the truth-value of a belief is not the crucial factor in its acceptance in public discussion. We shall see that 
both the Killer Weed and the Drop-out Drug images became prominent in the absence of logically compelling evidence and that the social milieus in which they arose were predisposed in their favor.

\section{Guiding Concepts}

Several social structural features that are likely to influence the image of marihuana can be gathered from the literature on drug controls that has developed in the last two decades. This literature has formulated numerous sociological explanations of drug controls, but three "guiding concepts" seem especially important - "entrepreneurship," "social locus," and "symbolic politics." These notions appear either individually or in various combinations in much of the drug literature; their classic formulations, however, can be found in the work of Howard Becker, Troy Duster, and Joseph Gusfield respectively [6]. By briefly examining these three works, we can identify the three guiding concepts and then redirect them from the study of drug controls to the somewhat different issue of marihuana ideology.

\section{ENTREPRENEURSHIP}

To understand drug controls, Becker urges us to pay attention to what organizations or organized social groups took the initiative to procure a particular drug law and how and why they did so. Moral rules, Becker reminds us, are not automatically created and enforced. Rule creation and enforcement require "moral enterprise," the specific effort by a formally constituted agent to transform established social values into specific rules and then to see to it that these rules are applied. Such an agent is a "moral entrepreneur."

\footnotetext{
Whenever rules are created and applied, we should be alive to the possible presence of an enterprising individual or group. Their activities can properly be called moral enterprise, for what they are enterprising about is the creation of a new fragment of the moral constitution of society, its code of right and wrong [7].
}

To procure a new moral rule, the moral entrepreneur must go through a characteristic process of publicizing the area of wrongdoing, enlisting organizational support, cultivating public opinion, and so on - a process that Becker traces in the case of the U.S. Federal Bureau of Narcotics and the Marihuana Tax Act.

To be sure, the role of entrepreneurship in the creation of drug laws is considerably more complex than Becker pictures it; there may be any number of moral (and presumably amoral) entrepreneurs contending to 
define the moral and legal status of a drug, and at different times different groups may show an interest in the social fate of a particular drug. In addition, although Becker takes for granted the ability and the willingness of a specific entrepreneur to create legislation regarding a specific drug (e.g., the Federal Bureau of Narcotics' ability and desire to direct the creation of the Marihuana Tax Act), these are in fact problematic. The power and interest of a specific entrepreneur depends on a variety of historical contingencies: the importance of the issue, the social status of the drug users, and the presence of other interested groups.

With these qualifications in mind, we can transfer the notion of entrepreneurship from the study of drug controls to the study drug ideology; organized social actors play a role not only in creating drug laws but also in developing, publicizing, and legitimating specific images of a drug. One key to the changing image of marihuana thus may be what moral entrepreneurs are available at various times to lend credibility and authority to particular images of the drug. In particular, we shall see that the rise of the Killer Weed image in the 1930s was tied to the dominance of public discussion of marihuana by the Federal Bureau of Narcotics, and the replacement of this image by the Drop-out Drug image in the 1960s reflected the demise of that dominance.

\section{SOCIAL LOCUS}

In contrast to the focus of "entrepreneurship" on who creates the rules, the notion that I shall call "social locus" directs our attention to who uses a drug. As developed by Duster, it posits a relationship between the moral and legal status of a particular kind of drug use and the social position of the groups identified as the primary or typical users; the lower the social position of the users, the more likely that use will be regarded as deviant, disreputable, and wrong. As the social location of use changes, so does its moral status. In Duster's words:

certain classes of persons in any society are more susceptible to being charged with moral inferiority than other classes of persons. The behavior in which persons indulge is often less important than the social category from which they come ... When it is part of the public view that the predominant perpetrators of the act come from the moral center, the act cannot long remain 'immoral' or deviant; it can become deviant again only under circumstances where the public conception is that the 'morally susceptible' classes are those who are the primary indulgers [8].

Duster cites the moral careers of opiate and alcohol use in the U.S. as examples. Up to the early $1900 \mathrm{~s}$, when opiate (primarily morphine) users were predominantly from the upper and middle strata (the "decent and respectable elements"), opiate addiction was regarded as an unfortunate 
malady, but not as inherently morally depraved or stigmatizing. In the late 1910s, when the peculiar restrictions of the 1914 Harrison Act made use by the lower strata (the "unrespectable elements") more visible than that of the higher strata, the moral status of opiate use changed: it was now seen as inherently depraved and sick. Alcohol use, in contrast, made the opposite journey: in the early 1900s, alcohol use was associated with the lower strata and thus was regarded as deviant. With the advent of Prohibition, which unlike the Harrison Act left no quasi-legal loopholes for the upper and middle strata, the (illicit) alcohol use of more respectable elements of society became publicly visible, "producing the conditions for a public reappraisal of the moral status of alcoholic consumption" [9].

The notion of "social locus" may be applicable to the specific claims made about drugs as well as to their general moral status. The public image of a drug and its effects depends in part on the social groups perceived as primary users and on the public stereotypes about these groups and about the typical ways in which they are deviant. In regard to marihuana, we shall see that the Killer Weed image developed in part because the drug's original perceived users were Mexican laborers and other lower-strata groups, who were publicly stereotyped as violent. This image persisted until the perceived user group decisively shifted to middle-class youth in the $1960 \mathrm{~s}$, whose expected types of deviance were quite different.

\section{SYMBOLIC POLITICS}

The concept of "symbolic politics" as presented by Gusfield understands drugs and drug controls as symbolic counters in wider social conflicts: at times of social conflict or stress, the drug use of a socially subordinate or insurgent group may become a symbol of the threat that this group poses to a relatively dominant or established social group or to the dominant social order. Legislation against drug use may thus become a way of reasserting the legitimacy of the existing social hierarchy and the hegemony of dominant social groups by symbolically condemning those groups which threaten that hierarchy and hegemony.

The alcohol prohibition movement in the U.S., Gusfield argues, is the prime example of this kind of symbolic politics. In the late nineteenth century, the Temperance Movement turned from "assimilative reform," an attempt to save individual drunkards, to "coercive reform," an effort to procure state and, ultimately, national legislation against the production and sale of alcohol. The new emphasis reflected the effort of a predominantly Protestant, native-born, rural, old middle class to reassert its social position in the face of a rising urban, corporate capitalist, industrial society and a growing Catholic immigrant working class. Prohibition was a symbolic asser- 
tion of the dominance of abstemious old middle class norms concerning alcohol use and of the old middle-class culture in general over more permissive alcohol norms and the new culture and classes that these norms symbolized: "The Eighteenth Amendment was the high point of the struggle to assert the public dominance of old middle-class values. It established the victory of Protestant over Catholic, rural over urban, tradition over modernity, the middle class over both the lower and upper strata" [10].

As with the other two concepts, "symbolic politics" may prove useful in understanding drug ideology as well as drug controls. The dominant image of a drug may be shaped partly by the substance's role as a symbol in wider social conflict. In the case of marihuana, we shall see that the rise of the Drop-out Drug image and the notion of the "amotivational syndrome" can be linked to the drug's role as a symbol of the political and cultural rebellion of middle-class youth in the 1960s and early 1970s.

\section{Methodology}

In the following discussion, we shall be interested in describing and explaining changes in the dominant image of marihuana in public discourse in the United States. Public discourse refers not to popular opinion (as reflected in survey research, for example) but rather to discussions of marihuana formally "open to common or general view" - in particular, what was said about the drug in hearings, periodicals, newspapers, and so on.

Two systematic samples of such materials were examined. The first consisted of periodical articles on marihuana indexed in the Readers' Guide to Periodical Literature. The Readers' Guide indexes articles by topic from a selection of general-interest periodicals. It covers a broad time span (1890 to the present), provides a presorted sample of articles on marihuana, and maintains a general consistency in the kind of periodicals indexed throughout the period under study. The sample was drawn from the "marihuana," "hashish," "cannabis," and "THC" categories in the Readers' Guide from 1890 to 1976 . It consisted of all articles in these categories from 1890 to $1966(N=56)$, and a random selection of one-fifth of the articles from 1967 to $1976(N=65)$. A limited selection of articles after 1966 was required by the sharply increased frequency of articles at the time.

The second sample of materials included all Congressional hearings and Federal reports that discussed marihuana from the early 1900s through 1976. The list was compiled from the major historical works on American drug controls and from several anthologies [11]. The reports included, among others, the 1931 Wickersham Commission volume on "Crime and the Foreign Born," the various inquiries into drug use commissioned by 
President Kennedy in the early 1960s, the 1972 marihuana report of the National Commission on Marihuana and Drug Abuse, and the annual assessments of "Marihuana and Health" by the National Institute on Drug Abuse. The hearings included the 1937 House and Senate hearings on the Marihuana Tax Act, the various hearings in the 1950s on narcotics and organized crime, and the rash of drug hearings in the late 1960s and early 1970s.

A variety of additional primary materials was also used - the official annual reports of federal narcotics authorities (Traffic in Opium and Other Dangerous Drugs), the 1945 report of the New York Mayor's Commission on Marihuana (the LaGuardia Report), and a sampling of books and newspaper articles.

A general reading of these materials was supplemented by a systematic quantitative content analysis of the Readers' Guide sample. Each article was coded for the effects it imputed to marihuana use to allow us to determine the prevalence of various claims at different time periods.

\section{Killer Weed: Failure of Restraint}

\section{VIOLENCE}

From the mid-1930s to the early 1960s, marihuana was characterized in public discussion primarily as a Killer Weed. Although the drug was said to produce a myriad of effects and was sometimes condemned as unpredictable in this regard, violence was the main adverse effect claimed for use: Marihuana was said to destroy users' internal controls, stimulate their aggressive drives, and lead them to assault, murder, rape, or self-destruction. The drug was believed to release a fundamentally destructive human nature and thus cause a failure of restraint.

The violence claim was central to the arguments made by narcotics officials against the drug. In one of its first detailed descriptions of the effects of marihuana [12], the Federal Bureau of Narcotics (FBN) enumerated the drug's various effects on consciousness - euphoria, stimulation of the imagination, kaleidoscopic visions, distortions of time and space perception - and then argued:

\footnotetext{
The principal effect of the drug is upon the mind which seems to lose the power of directing and controlling thought. Its continued use produces pronounced mental deterioration in many cases. Its more immediate effect apparently is to remove the normal inhibitions of the individual and release any antisocial tendencies which may be present. Those who indulge in its habitual use eventually develop a delirious rage after its administration, during which time they are, temporarily at least, irresponsible and prone to commit violent crimes [13].
}

While mental deterioration received no further attention, the violence theme 
was supported by quotes from appropriate authorities and by examples of "marihuana crimes" [14].

Similarly in a 1937 American Magazine article, FBN Commissioner Harry Anslinger stressed the violence theme, arguing that marihuana "addicts may often develop a delirious rage during which they are temporarily and violently insane; . . . this insanity may take the form of a desire for self-destruction or a persecution complex to be satisfied only by the commission of some heinous crime" [15]. Anslinger spent much of the article supporting this violence claim with more examples of marihuana-induced crimes.

Up through the early 1960s, the FBN's annual reports continued to list spectacular examples of marihuana crimes and, even as late as 1966, the Bureau stressed the violence theme. At the 1966 Senate Judiciary Committee hearings on the Narcotic Rehabilitation Act, Bureau Commissioner Henry Giordano, who had succeeded Anslinger four years previously, summarized the dangers of marihuana as follows:

From my studies and experience, one theme emerges - that marihuana is capable of inducing acts of violence, even murder. The drug frees the unconscious tendencies of the individual user, the result being reflected in frequent quarrels, fights, and assaults [16] .

The violence claim also dominated the 1937 Congressional hearings on the Marihuana Tax Act, the most extensive public discussion of marihuana prior to the 1960s. At the hearings before the House Ways and Means Committee (which were substantially longer and more complete than the very brief hearings before the Senate Finance Committee), representatives of the FBN again stressed that marihuana use stimulated violent behavior by dissolving moral restraints, destroying the ability to judge right and wrong, stimulating grandiose fantasies, and making the user highly suggestible. Violence was also the central theme of the three articles and of two of the four letters submitted as exhibits to the committee. No other allegation received even a fraction of that attention [17].

Periodical articles from the mid-1930s to the early 1960s also focused on the violence theme. Between 1935 and 1940, the period of most intensive attention given to marihuana, $85 \%$ of the twenty Readers' Guide articles that discussed specific effects at all mentioned violence; between 1935 and $1963,63 \%$ of the 35 articles that addressed the issue did. In contrast, only a few articles mentioned addiction, passivity, stepping-stone, accidents, sexual debauchery, or other specific effects. More importantly, violence was virtually the only theme that received detailed attention. The claim that marihuana stimulated aggression was discussed at length and was buttressed by various legends and alleged cases of marihuana-induced crime.

We cannot adequately appreciate the importance of the violence claim in 
public discussion of marihuana, however, simply by noting the frequency and extent of references to it. Violence was not simply quantitatively predominant; it also was central to the images of user and drug and thus provided a framework for the entire discussion. It was seen not simply as the major effect of marihuana use but as the essential characteristic of the user as well. Especially during the late 1930s, when periodicals described theuser, they pictured either a violent fiend or an innocent victim turned violent fiend; marihuana users were "criminals, degenerates, maniacs" in the words of Survey Graphic and Forum and Century [18].

The violence claim also was a way of conceptually organizing and understanding the many other effects imputed to marihuana. Each was seen primarily as a way in which marihuana made the user violent and thus carried connotations of crime and aggression. As the 1936 FBN report put it, marihuana use generated violence by removing normal inhibitions and releasing antisocial tendencies. This twin theme of irresistible impulses and destruction of the will was repeated frequently in periodical articles [19]. Anslinger's 1937 article linked violence to insanity and to a persecution complex. The latter in turn was said by others to arise from the delusions and hallucinations brought on by the drug; those not subject to delusions of persecution might be prone to "acute erotic visions," which would lead them to commit forcible rape [20].

When viewed from the perspective of the Killer Weed image, even the most elementary effects of marihuana on consciousness took on a sinister cast. Simple distortions of time and space perception and disturbances of connected thought were said to confuse the mind in such a way that the "slightest impulse or suggestion carries it away" [21]. Heightened suggestibility itself was also regarded as a cause of violence, because it was used by "leaders of gangs and criminals" to lure the innocent into crime [22].

In short, nearly every other effect imputed to marihuana was implicated in the drug's violence-producing tendency and interpreted accordingly. The Killer Weed image tied these disparate effects together and gave them coherence. What we are dealing with, then, is not merely a specific claim about marihuana but a general image of drug and user that oriented public discussion.

Having shown the centrality of the Killer Weed image to the discussion of marihuana from the 1930s onward, we can turn to the question of how it got to be that way. We can explain its predominance by tracing its history and examining especially the initial social locus of marihuana use and the entrepreneurial activity of the Federal Bureau of Narcotics. 
Prior to the 1930s, among those few who considered the issue, there was no consistent nationwide image of marihuana use and the problems it caused. The seven articles in the Reader's Guide between 1890 and 1931 show little agreement on how dangerous marihuana was, what its major effects were, or even what name to call it. The last of these is particularly interesting; by the mid-1930s, the drug would be generally known as "marihuana," but until then it had several identities. As a medical preparation and an object of scientific interest, it was "cannabis"; as an intoxicant found in Mexico and along the Texas border, it was "marihuana"; and as an Eastern drug identified with Arabs and Indians, it was "hashish" or "Indian Hemp." The multiplicity of terms implies that the drug had no settled social image.

The very fact that the drug ultimately became known as "marihuana" in the 1930s suggests that the social image that became dominant then had roots in the Southwest. Indeed, this appears to be the case. Marihuana use was first introduced into the U.S. on a significant scale in the 1910s by immigrant Mexican laborers in the Southwest, from where it spread principally to various lower strata groups in New Orleans in the 1920s [23]. In both these places an image of marihuana - tying together the drug, violence, and Mexican laborers and other lower-class groups - developed along with the diffusion of use.

Marihuana use was hardly a big issue in the Southwest at the time, but the attention it did receive came in the context of specific anti-Mexican stereotypes. Mexican laborers were often perceived as "criminal types," noted for carrying knives and being drunk and disorderly; marihuana was clearly associated with Mexican laborers. As a result, marihuana also became associated with violence. It became a Killer Weed.

The idea that marihuana use made Mexican laborers violent was well established among upper-strata Mexicans in both Mexico and the U.S. in the early 1900s [24]. As Mexican laborers moved through the Southwest to take the cheap agricultural jobs available from Texas to California and further north, they brought marihuana and the Mexican laborer-marihuana-violence image with them. The stereotype was pointedly presented as early as 1913 in a Cosmopolitan short story by Alfred Lewis, Hearst reporter and well-known writer on the Southwest. The story concerns the ill-fated adventures of an errant Harvard graduate who is attracted to Mexicans and marihuana in a border town and ultimately becomes so violent that he must be killed in self-defonse. Lewis's narrator makes it quite clear that Mexicans are typically violent and useless except to "shoot at when 
you wants to unload an' clean your gun," that marihuana is a Mexican drug, and that marihuana induces violence: "Once old marihuana wrops its tail about your intellects, you becomes voylent an' blood-hungry, an' goes on the onaccountable war-path, mighty deemoniac" [25].

This image of marihuana as a Killer Weed was common whenever the drug was discussed in the Southwest in the 1910s and 1920s. Reports on marihuana by the Department of Agriculture in 1917 and by U.S. Canal Zone authorities in 1925 cite numerous accounts by law enforcement officials and newspapers regarding the connections between marihuana, Mexicans, and violence. The brief legislative discussions that preceded the passage of antimarihuana legislation in numerous southwestern and western states often made pointed references to the drug's Mexican origins and violent effects. California crime studies in the 1920s noted the high rates of crime and delinquency among Mexicans, and the state's narcotics reports identified marihuana as a Mexican drug [26].

The perception of marihuana as a Killer Weed developed also in New Orleans in the 1920s in connection with use by various lower-strata groups. At several times in the 1920s and early 1930s, marihuana use was a greater public issue there than anywhere else in America at the time. In 1920, Louisiana Governor John Parker, alerted to the dangers of marihuana by the president of the Louisiana Board of Health, wrote the Prohibition Commissioner that the drug made people go "crazy and wild" [27]. The New Orleans police staged a major crackdown on "marihuana and vice" in 1926, which was prominently reported by the local press [28].

New Orleans public officials and private citizens wrote several articles in the early 1930s describing the evils of the drug - articles that would be frequently cited directly and indirectly in subsequent years [29]. The authors agreed that marihuana made the user violent. Indeed, their perceptions are summed up neatly by the title of Eugene Stanley's article: "Marihuana as a Developer of Criminals." Both Stanley and A.E. Fossier, whose articles were nearly identical, described the users simply as of the "criminal class." Frank Gomila and Madeline Lambou asserted that marihuana dealers were "Mexicans, Italians, Spanish-Americans, drifters from ships" and that users included dock workers and sailors, Negroes ("Practically every Negro in the city can give a reasonable description of the drug's effects"), Mexicans, and "vicious characters." The New Orleans image of marihuana and violence, in short, developed in tandem with a perception of the users as either members of racial minorities or as lower- and working-class whites.

In the early 1930s, the New Orleans-Southwest image of marihuana use found its way into the discourse of federal law enforcement officials and from there into general public discussion. Prior to that time, marihuana received scant federal attention; and, when the drug was discussed (as in a 
1929 Surgeon General's report and a law establishing "narcotics farms" for treating addicts), it was called "Indian Hemp" and not regarded primarily as a Killer Weed. In contrast, the New Orleans-Southwest image of marihuana was reflected (but not consistently endorsed) in the 1931 Wickersham Commission Report on "Crime and the Foreign Born," which paid considerable attention to the fact that Mexicans, unlike most foreign-born groups, had higher official crime rates than native-born whites. While concluding that the high rates were rooted in discrimination, social conditions, and cultural differences, it documented at some length the belief of judges and police officials in areas with high Mexican populations that Mexicans were inherently violent. The Report also noted that Mexicans were tied closely to drug use and described marihuana as a "drug the use of which has spread with the dispersion of Mexican immigrants" and "is widespread throughout Southern California among the Mexican population." Finally, it described marihuana as a violent drug in a citation from a publication of the California State Narcotics Committee: "if continued, the drug develops a delirious rage, causing the smoker to commit atrocious crimes" [30].

The New Orleans-Southwest stereotype insinuated itself into the perceptions of federal narcotics officials as well. The Wickersham study and the 1917 Department of Agriculture investigation made their way into the Bureau's files, and a New Orleans FBN agent forwarded Stanley's article to his superiors in Washington [31]. FBN Commissioner Anslinger reported in retrospect that his first perceptions of marihuana were based on reports from southwestern and western states where there was concern about the behavior of Mexicans who, "the sheriffs and local police departments claimed, got loaded on the stuff and caused a lot of trouble, stabbings, assaults, and so on" [32].

It is not surprising, then, that when federal narcotics officials first referred to marihuana, they described its users as "Spanish-speaking" and "Latin American." Several years later, when the FBN began publicizing the effects of the drug, it stressed violent crime [33]. Drawing its image of marihuana largely from New Orleans and the Southwest, the Bureau simply came to see the drug as "obviously" a Killer Weed, a producer of violence and crime.

\section{THE BUREAU'S HEGEMONY}

When the Bureau began to publicize the "marihuana menace" in late 1934, it stressed the Killer Weed image, and this image became diffused into the general public discussion of marihuana because the Bureau effectively dominated this discussion. The public image of marihuana from the mid1930s through the early 1960s was largely what the Bureau dictated; those 
who wrote or talked about the drug relied heavily on the Bureau and its sources.

The Bureau dominated the Congressional hearings on the Marihuana Tax Act; it presented the bulk of the testimony, sponsored most of the other significant witnesses, and submitted most of the accompanying materials. In doing so, it introduced the Stanley and the Gomila-Lambou articles into public discussion and stressed the colorful evidence for marihuana's violenceinducing propensity cited by Stanley: several Oriental myths about marihuana use and a second-hand report of a New Orleans jail study that claimed that one-third of the prisoners were marihuana "addicts." Opposition to the Bureau was largely technical or half-hearted. Manufacturers of rope, hempseed, and hemp oil were easily convinced that an anti-marihuana law would not interfere with their business, and the American Medical Association's complaint that a new drug law meant more redtape for physicians got nowhere.

The Bureau also influenced the content of most periodical articles either directly or indirectly. Between 1935 and 1940, for example, besides the one article actually co-authored by Anslinger, seven articles explicitly credited the Bureau or its commissioner as the source of information [34]. Several articles repeated almost verbatim the Old World marihuana legends found in Stanley and popularized by Anslinger - that hashish was used by the Islamic sect of Assassins to fortify themselves for political murders, that it made the Malays run "amok," and that it was the "nepenthe" that Homer said "made men forget their homes" [35]. Others cited the Stanley prisoner study and the Gomila-Lambou two-fold crime theory that marihuana both caused unpremeditated violence and was used by criminals to fortify themselves for premeditated crimes [36].

Examples of marihuana crimes from Anslinger's 1937 article, moreover, were repeated incessantly - the Texas hitchhiker who murdered a motorist, the West Virginia man who raped a nine-year-old girl, the Florida youth who ax-murdered his family, the Ohio juvenile gang that committed 38 armed robberies, the Michigan man who killed a state trooper, and other equally blood-curdling tales. In short, discussion of marihuana in the late 1930s drew heavily on the Bureau and its favored sources; sixteen of the 22 Readers' Guide articles between 1935 and 1940 bear the direct or indirect marks of the Bureau.

Just as periodical articles generally used the information propagated by the Bureau, they virtually ignored information that the Bureau ignored. Studies by the Indian Hemp Commission in 1894, the U.S. Canal Zone Committee in 1926 and 1933, and Walter Bromberg in 1934, all of which distinctly downplayed the dangers of marihuana use in general and the 
violence claim in particular, were rarely mentioned during the period, though all were available.

The Bureau's dominance continued through the 1940s and 1950s and even into the 1960s. Its rejection of the findings of the 1945 LaGuardia Report, which again questioned the dangers of marihuana, was generally accepted. Its new claim that marihuana use led to the use of harder drugs, first voiced in its 1949 report, gained common-sense status quickly. In hearings on the Boggs Act (to increase penalties for narcotics offenses) two years later, it was already regarded as a "tragically familiar story" [37].

The Bureau's success in dominating public discussion for several decades rested on specific social conditions. The Bureau succeeded because marihuana use prior to the 1960s was an insignificant issue, because no other organized groups had an interest in the fate of the drug, and because its users were socially marginal and few in number. Hardly anyone knew about marihuana or had an interest in it. The populace at large hardly knew its name; there were few sources of information other than the Bureau; and the declining medical use of the drug by the 1930s had given manufacturers, physicians, and pharmacists only a token interest in opposing the Bureau's propaganda. In such circumstances, the Bureau could shape the image of marihuana with minimal effort and with little likelihood of opposition or rebuttal. The paucity and marginality of the users, moreover, made it unlikely that otherwise reputable citizens would be arrested, that non-users would have any first-hand experience with users, or that the users themselves would effectively organize. The Bureau's hegemony thus was not disturbed by other interest groups, organized users, or a concerned general public. As we shall see, in the 1960s, all this would change.

\section{SUMMARY}

In short, marihuana became known as a Killer Weed for two reasons. The first was its initial social locus of use. Marihuana was seen as a drug typically used by Mexican laborers and other lower-strata groups; these groups were perceived as typically becoming deviant in violent ways. Marihuana thus became known as a drug that typically produced violence. This image of marihuana developed in the Southwest and New Orleans and was transmitted by local officials and narcotics agents to the relevant authorities in the federal government. The second reason was the entrepreneurship of the Federal Bureau of Narcotics, which dominated public discussion and gave the Killer Weed image credibility and legitimacy. Once established, the image persisted partly because of continued FBN publicity, partly because of inertia; the more the claim was repeated, the more it was likely to be 
repeated, until significant social changes rendered the old image obsolete and created a new image to replace it.

The Killer Weed image, moreover, arose and persisted despite a lack of any "compelling" evidence for it. Indeed, the only available evidence for the violence claim has already been mentioned: a second-hand report of a prisoner study, some time-honored Old World legends, and several cases of alleged marihuana-related crimes.

\section{Drop-out Drug: Failure of Achievement}

\section{THE AMOTIVATIONAL SYNDROME}

The Killer Weed image virtually disappeared from public discussion in the middle and late 1960s. Federal narcotics officials pushed it at the Narcotic Rehabilitation Act hearings in 1966 and again at the 1968 House hearings on hallucinogen control, but these were the last times any major witness mentioned the marihuana-violence connection [38]. The violence claim was virtually absent from the numerous lengthy drug control hearings of the late 1960s and early 1970s. In its 1972 report on marihuana, the National Commission on Marihuana and Drug Abuse concluded flatly that "marihuana does not cause violent or aggressive behavior," and even Senator James Eastland's 1974 hearings on the "marihuana-hashish epidemic" managed to omit any mention of violence from the almost endless list of dangers it attributed to marihuana [39]. The violence claim disappeared also from periodical articles, and by 1971, narcotics officials had abandoned it as well. John Ingersoll, head of the Bureau of Narcotics and Dangerous Drugs, stressed instead that marihuana was "psychologically habituating, often resulting in an amotivational syndrome" [40].

To an extent, the Killer Weed image was replaced by the belief that marihuana was not an especially dangerous drug in any respect. For many, though, what changed was not the degree of danger, but the kind. The most common claim now was that marihuana use destroyed ambition and initiative, undermined the effort to cope with the world, and facilitated withdrawal from reality. It led, in the National Commission's words to "lethargy, instability, social deterioration, a loss of interest in virtually all activities other than drug use" [41]. Marihuana, in other words, destroyed the structured, active, achieving, outgoing part of the personality and thus uncovered the essentially passive, ambitionless, solipsistic human nature hidden underneath. It was now a Drop-out Drug; it caused a failure of achievement, or in common parlance, an amotivational syndrome. Like the Killer Weed, the Drop-out Drug in effect destroyed the user's self-control and released the 
basically anti-social human nature held in check by it. The difference lay in how this underlying human nature was pictured: aggressive in the one case, passive and ambitionless in the other.

Although it had received scant attention prior to the 1960 s, the passivity claim was the most common danger attributed to marihuana by the articles in the Readers' Guide sample between 1964 and 1976, being mentioned by $35 \%$ of the articles (to be sure, not a majority). More importantly, the claim dominated judicial deliberations, Congressional hearings, and federal reports.

In his landmark 1967 decision upholding the constitutionality of Massachusetts' marihuana law, Judge G. Joseph Tauro described marihuana use as follows:

Many succumb to the drug as a handy means of withdrawing from the inevitable stresses and legitimate demands of society. The evasion of problems and escape from reality seem to be among the desired effects of the use of marijuana [42].

The charge of passivity and withdrawal was first voiced in Congressional hearings in 1968 by Dr. Donald Louria, of the New York State Council on Drug Addiction:

Drug-induced withdrawal is a problem of increasing severity in our society, and LSD is only one vehicle for this. Even marihuana in heavy doses can, after repeated use, produce the same loss of ambition, rejection of previously established goals, and retreat into a solipsistic, drug-oriented cocoon [43].

In the 1969-1970 hearings on the Comprehensive Drug Abuse Prevention and Control Act, the amotivational syndrome was the major claim made against marihuana, being mentioned in eight of the eleven major pieces of testimony that discussed adverse effects [44]. It was, moreover, the only danger that was stressed or discussed at length. For example, Roger Egeberg, Assistant Secretary for Health and Scientific Affairs in the Department of Health, Education, and Welfare, made the following point:

Marihuana use, particularly because it starts at such an early age, is apt to make many poople go off into a pleasant euphoria or other means of evading reality at a time, $15,16,17,18$ years when they should be setting their aims . . . This $I$ would say is the tragedy to all of society with respect to the use of marihuana [45]. (emphasis added)

Dana Farnsworth of the Harvard University Health Services also focused on the amotivational syndrome:

But I am very much concerned about what has come to be called the 'amotivational syndrome'. I am certain as I can be ... that when an individual becomes dependent upon marihuana ... he becomes preoccupied with it. His attitude changes toward endorsement of values which he had not before; he tends to become very easily satisfied with what is immediately present, in such a way that he seems to have been robbed of his ability to make appropriate choices [46]. (emphasis added) 
The 1972 report of the National Commission on Marihuana and Drug Abuse took the "amotivational syndrome" more seriously than any other potential adverse effect of marihuana. While downplaying most of the commonly claimed dangers and giving moderate use a clean bill of health, the report was careful to stress that the amotivational syndrome was a real danger for heavy users and might become a major problem in the United States as use increased. More importantly, the National Commission noted a pervasive societal concern about an amotivational syndrome. In discussing "why society feels threatened," the report noted that parents were concerned that "marihuana will undermine or interfere with academic and vocational career development and achievement" or, even worse, that it will lead to "amotivation" and "dropping out" [47].

Senator Eastland's 1974 hearings pictured the amotivational syndrome as the most significant behavioral effect of marihuana use:

The most notable and consistent clinical changes that have been reported in heavy marihuana smokers include apathy approaching indolence, lack of motivation . . reduced interest in socializing, and attraction to intense sensory stimuli .... Possibly the issue of greatest importance in the area of behavioral toxicity of marihuana is the question of the amotivational syndrome [48].

The amotivational syndrome was mentioned by twelve of the fourteen witnesses who testified on the behavioral effects of marihuana - several times as often as any other adverse effect, and it was the only behavioral effect to be systematically discussed - by Harvey Powelson, Hardin Jones, and Harold Kolansky and William Moore [49].

Beyond its mere quantitative frequency, the amotivational syndrome also provided a frame for discussing the other adverse effects of marihuana and for constructing an image of the user as a person. It thus played the same pivotal cognitive role that violence did in the 1930s. Psychological dependence, the second most frequently mentioned adverse effect in the 1960s and early 1970s, was basically a synonym for the amotivational syndrome; both claims implied that the heavy marihuana user became totally wrapped up in drug use and lost interest in everything else. The brain damage and lowered testosterone levels (in males) caused by marihuana use were partly interpreted as the direct causes of the amotivational syndrome. The former was said to limit the user's cognitive ability to deal with the world, and the latter to lead to a general reduction in drive [5]. The putative link between marihuana use and automobile accidents was understood to result from the user's reduced ability to cope with the world.

Those who sought to typify marihuana users implicitly described them as embodiments of the amotivational syndrome. Passivity, lack of motivation, withdrawal from reality, and an inability to cope were not seen as some 
of the user's many traits, but as master traits that defined his very existence. In Judge Tauro's adjectival overkill, marihuana users were-"the disaffiliated, the neurotic and psychotic, the confused, the anxious, the alienated, the inadequate, the weak" [51]. For Hardin Jones, the amotivational syndrome was nothing less than a whole lifestyle of "dropping out, indolence, lowering of goals, alienation" and "kookiness" [52].

In short, the amotivational syndrome was not simply one important effect imputed to marihuana; it formed the core of the dominant image of both drug and user. Marihuana did not simply cause an amotivational syndrome (among other things); it was in essence a Drop-out Drug. The rise of the Drop-out Drug image can be seen as the result of the demise of the FBN's dominance of public discussion, the increase in middle-class use, and the emergence of marihuana as a symbol of the Counterculture.

\section{DEMISE OF THF, BUREAU'S HEGEMONY}

The shift from Killer Weed to Drop-out Drug resulted in part from the decline of the monopoly of the Federal Bureau of Narcotics over the marihuana issue. In the early 1960s, President Kennedy initiated a series of White House conferences, panels, and commissions on "narcotics and drug abuse" that effectively opened up the discussion of marihuana to other government agencies and interested groups [53]. Later in the decade, the rapid increase in marihuana use made the drug a major social issue for the first time - the subject of widespread popular debate, headlines, and endless hearings and reports.

The basis of the Bureau's dominance of the marihuana issue was thus undermined. Marihuana became an important matter; other interested groups (notably scientists, physicians, and public health officials) became involved; users themselves became a force in their own right; and the general populace was aroused. What had once been a small-scale, uninterrupted monologue became a wide-ranging, raucous cacophony of voices, and narcotics officials could not hope to dominate a public discussion of such scale and diversity. The main proponent of the Killer Weed image thus lost ground, while the very diversity of voices created the opportunity for a new image of marihuana to emerge. As changes in the social locus of use and the symbolic meaning of the drug generated a Drop-out Drug image, there were spokesmen (primarily public health officials and physicians) available to publicize and legitimate it. 
The emergence of youthful middle-class marihuana users also led to the rise of the Drop-out Drug image. In the 1920s and 1930s, when Mexican laborers and other lower-strata groups had been perceived as the primary users of marihuana, the drug had been seen as creating the kind of deviant behavior regarded as typical of those groups - aggression or a failure of restraint. In the 1960s, marihuana use among middle-class youth increased rapidly and was quickly recognized; the first articles announcing the increase of marihuana use in suburbs and on campus began appearing in 1964 and 1965 [54]. The typical using group thus became middle-class youth. If violence was the kind of deviance expected from lower-strata groups, then a failure to achieve, a loss of motivation and initiative, appeared as the typical way that middle-class kids went bad and as the ultimate failure of middleclass socialization. They were expected not to commit violent crimes or go insane in any spectacular way but rather to drop out or squander their potential. The dangers attributed to marihuana changed accordingly from the deviance expected from the older using group to that expected from the newer group - from violence to amotivation or a failure of achievement.

\section{MARIHUANA AND THE COUNTERCULTURE}

Finally, the image of marihuana changed because the drug became a symbol in the wider social struggle between the dominant society and the Counterculture. As used here, "Counterculture" refers to the political and cultural rebellion of middle-class youth during the late 1960s and early 1970 s as well as to those who participated in this rebellion in its widest sense - not only those who became involved in radical politics or experimented with alternative lifestyles but also the much larger number who shared the sense of alienation and the value commitments that fostered these activities.

"Symbol" implies something that not only refers to but also embodies something else and thus is responded to as if it were that other thing; in other words, a symbol invokes in us the same experience as the object it symbolizes. As Jaeger and Selznick put it:

the symbol itself takes on the human significance possessed by its referent. To the naturalist, the flock of birds may be a sign of land, and nothing more. To the sailor long at sea, the flock of birds may acquire symbolic status and he may respond to them much as he will later respond to his actual homecoming. Black may be merely a denotative sign of death, death merely a natural sign of disease. But when black is truly a symbol of death, we respond to it much as we would humanly respond in the presence of death [55]. 
For many in the late 1960 s and early 1970 s, marihuana not only was associated with the Counterculture but also came to embody it. They responded to the one as if it were the other.

The symbolic status of marihuana was occasionally directly acknowledged in public discussion, and an effort was sometimes made to distinguish the drug's effects from its meaning. In a 1972 National Review article, for example, Jeffrey Hart argued that the evils of marihuana lay in its meaning, not its effects ("I care not a fig for its physical effects"): marihuana symbolized the Counterculture, and the main purpose of anti-marihuana laws was "to lean on, to penalize the counterculture" [56]. For their part, proponents of penalty reduction took pains to argue that marihuana should not be regarded as anything more than a drug. The National Commission explicitly "tried to desymbolize" marihuana so as to build support for decriminalization [57]. Several studies of the uproar over marihuana in the late 1960s and early 1970s also attempted to root opposition to the drug in its symbolic meaning as distinct from its effects [58].

Public discussion of marihuana, however, rarely drew such a neat distinction between meaning and effects, and the most significant consequence of the transformation of marihuana into a symbol lay in the ways the effects themselves were reconceptualized. When these effects were discussed, they were described in a way determined by the fact that marihuana was the symbolic embodiment of the Counterculture. The social characteristics of the Counterculture, as perceived by the dominant society, were projected onto marihuana and then said to be psychological effects inherent in the drug; because the Counterculture was characterized as passive and escapist, marihuana became seen as a producer of passivity and escape on the individual level. The amotivational syndrome, in other words. was simply the Counterculture writ small and turned into a psychiatric diagnosis.

Once established, the new image of marihuana persisted because it was functional; it reinforced a way of explaining the Counterculture that was simultaneously a way of explaining it away, of accounting for it without having to come to terms with it. The easiest way to condemn youthful rebellion was to describe it in purely negative terms - as dropping out from organized social life, as escaping from reality, as failure. In this way, the adult generation and the dominant society did not have to acknowledge and deal with what youth were doing but only with what youth were not doing. They did not have to confront the youthful rebels' philosophical, moral, and political commitments or the alternative world that they were trying to build, in however halting, half-hearted, and incomplete a way. The image of marihuana as a source of an amotivational syndrome facilitated this purely negative viewing of the Counterculture, because, if the amotivational syndrome was simply the Counterculture writ small, the Counterculture in turn 
could be seen simply as the amotivational syndrome writ large. The amotivational syndrome provided a seemingly simple, delimited model on the psychological level for understanding a more complex, diffuse, and thus harder-to-grasp phenomenon on the cultural level.

Contemplated in itself, the Counterculture might have been too complex to support a simple image of it as a mere negation or dropping out. Viewed as a giant version of the amotivational syndrome, it was casier to understand and dismiss. The assessment of the amotivational syndrome was unassailable; it was unambiguously negative - loss of motivation, escape from reality, passivity. As a syndrome, moreover, it was a psychiatric condition with clear overtones of pathology. As the amotivational syndrome writ large, the Counterculture too appeared as unquestionably negative, and its negativity appeared as something specific and palpable - a mass psychiatric syndrome. The discrediting view of the Counterculture was thus reinforced by its association with marihuana conceived as the source of the amotivational syndrome.

To restate this in a sentence: marihuana simply functioned effectively as a cultural symbol. It provided a "template" for organizing and making sense of a multitude of impressions of the Counterculture -- to usc Geertz's terminology. It served as a "sensuous embodiment of what is abstract and ineffable" - to use Jaeger's and Selznick's phrase [59].

The public images of drug and culture, in short, were mutually reinforcing. Because its use symbolized a cultural phenomenon that was widely seen as a mere passive withdrawal from reality, marihuana ceased to be seen primarily as a Killer Weed and became instead a Drop-out Drug. Because the Counterculture was symbolized by a Drop-out Drug, its reputation as a pathological denial of society was made palpable and thus reinforced.

\section{SUMMARY}

In short, the shift from Killer Weed to Drop-out Drug occurred for three reasons. First, the main proponent of the Killer Weed image, the Federal Bureau of Narcotics, lost its dominance of the public discussion of marihuana, and the subsequent plurality of voices allowed a new image to emerge. Second, the social locus of use changed; middle-class youth became seen as the primary users of marihuana, and the image of marihuana changed to reflect the typical kind of deviance expected of this group. Finally, marihuana became involved in the cultural and political conflict of the late 1960 s and early 1970s as a symbol of the Counterculture and thus became an embodiment of the latter. 
Like the Killer Weed image, the Drop-out Drug image became prominent without any really compelling evidence in its favor. At the 1974 Senate Judiciary Committee Hearings, for example, the argument that marihuana caused an amotivational syndrome was based solely on case studies drawn from clinical populations. Most of it was a trifle unsystematic. Several witnesses referred to their clinical experience in an offhand, anecdotal way. Another, a medical physicist with no psychiatric training, claimed to have interviewed some 1,600 marihuana users and to have seen "some degree of amotivational syndrome in all of them." He mentioned no control group, however, nor did he specify the composition and source of his sample, the nature and extent of the interviews, or the criteria used to identify the amotivational syndrome. The only other data was supplied by two psychiatrists who claimed that the 38 marihuana users they had seen in their private practices exhibited a distinctive amotivational syndrome that disappeared when use was discontinued. Their study, however, provided no basis for inferring the prevalence of an amotivational syndrome among the general population of marihuana users.

\section{Conclusion}

The evils attributed to marihuana use in the United States changed radically in the mid-1960s. Prior to that time, marihuana use was said to produce violence and aggression; since then, it has been said to cause virtually the opposite, passivity and amotivation. This transformation from Killer Weed to Drop-out Drug involved a change not only in specific beliefs about the effects of marihuana use but also in the general images of the drug and its users. What changed, in other words, were the basic assumptions underlying the entire public discussion of marihuana.

The shift can be explained by situating the public discussion of marihuana in social context. In particular, we have attempted to link it logically and historically to changes in (1) the array of organized social actors in the drug control arena; (2) the social background of marihuana users; and (3) the role of marihuana as a symbol in wider social conflicts. The importance of these factors in explaining the changed image of marihuana reaffirms the value of the guiding concepts upon which they were based and which in turn were extracted from the sociological literature on drug controls - entrepreneurship, social locus, and symbolic politics.

More generally, the analysis set out here suggests that the beliefs which prevail in public discussion of a particular kind of behavior depend upon (1) what organized social actors are available to give a specific set of beliefs legitimacy and credibility; (2) what social groups are identified with the behavior and what the prevailing stereotypes about those groups are; and (3) 
what the symbolic content (if any) of the behavior is. The beliefs that are likely to prevail are those which are advocated by the dominant organized actors in a particular arena of public discussion, those which are consistent with the general stereotypes about the social groups associated with the behavior in question, and those which are consistent with whatever symbolic meaning the behavior has.

Finally, our sociological account of the radical shift from Killer Weed to Drop-out Drug does not suggest that either of these images is necessarily false. Explaining a belief sociologically does not in itself invalidate it (and, conversely, not only false beliefs require sociological explanation). The analysis presented here, however, does imply that it is either false or misleading to regard truth-value or perceived truth-value as the crucial factor in the public acceptance of a belief. It also implies that even the most basic, takenfor-granted beliefs may be both historically variable and socially conditioned.

\section{Notes}

*This article is based upon The Strange Career of Marihuana: Politics and Ideology of Drug Control in America, to be published by Greenwood Press. It appears here with the permission of the publisher. The author would like to thank the following persons for their comments and assistance with various versions of the manuscript: Don Cahalan, Troy Duster, William Gamson, Ilarry G. Levine, Patricia Morgan, Robin Room Guy Swanson, Sheila Wilder, Mayer Zald, and the staff of the Alcohol Research Group (Berkaley, Ca.). The research upon which this article is based was funded by grants from the California Office on Alcoholism and the National Institute on Alcohol Abuse and Alcoholism.

1 E. Rowell and R. Rowell (1939), On the Trail of Marihuana: The Weed of Madness, Mountain View, California: Pacific Press.

2 "Pot problem," Time 85 (March 12, 1965): 49; B. Spock (1971), "Preventing drug abuse in children," Redbook 137 (May): 36+.

3 See H.S. Becker (1963) Outsiders: Studies in the Sociology of Deviance, New York: Free Press; R.J. Bonnie and C. Whitebread II (1974), The Marihuana Conviction: A History of Marihuana Prohibition in the United States, Charlottesville, Virginia: University of Virginia Press; S.J. Cook (1970), Variations in Response to Illegal Drug Use, Toronto: Alcoholism and Drug Addiction Research Foundation; D.T. Dickson (1968), "Bureaucracy and morality," Social Problems 16: 145-156; R. King (1974), The Drug Hang-up, Springfield, Illinois: Charles Thomas.

4 R.J. Bonnie and C. Whitebread II (1974), op. cit., 228.

5 T. Gitlin (1980), The Whole World is Watching: Mass Media in the Making and Unmaking of the New Left, Berkeley: University of California Press, p. 7.

6 H. Becker (1963), op. cit.; T. Duster, The Legislation of Morality, New York: Free Press; and J. Gusfield (1963), Symbolic Crusade, Urbana, Illinois: University of Illinois Press.

7 H. Becker (1963), op. cit., 145.

8 T. Duster (1970), op. cit., 247.

9 Ibid., 248.

10 J. Gusfield (1963), op. cit., 7.

11 R.J. Bonnie and C. Whitebread II (1974), op. cit.; E. Goode (1970), Marijuana, New York: Atherton Press; S.E. Grupp (1971), Marihuana, Columbus, Ohio: Charles E. Merrill; K.A. Kerr 
(1973), The Politics of Moral Behavior: Prohibition and Drug Abuse, Reading, Massachusetts: Addison-Wesley; R. King (1974), op. cit.; A. Lindesmith (1965), The Addict and the Law, New York: Random House; D. Musto (1973), The American Disease, New Haven: Yale University.

12 A few words on American drug control agencies. Prior to 1930, two agencies shared narcotics control functions. The Commissioner of Prohibition enforced the 1914 Harrison Act, a tax measure controlling domestic production and distribution; and the Federal Narcotics Control Board enforced the 1922 Narcotics Drug Import and Export Act. These two functions were combined in 1930 in the Federal Bureau of Narcotics, a new agency in the Treasury Department. In 1968, narcotics control was moved to the newly created Bureau of Narcotics and Dangerous Drugs in the Justice Department, where it was combined with the control of the illicit use of prescription drugs (previously under the aegis of the Bureau of Drug Abuse Control). In 1973, the BNDD was combined with two other recent creations, the Office of National Narcotics Intelligence and the Office for Drug Abuse Law Enforcement, to form the Drug Enforcement Administration.

13 U.S. Federal Bureau of Narcotics (FBN) (1936), Traffic in Opium and Other Dangerous Drugs, pp. 59-60.

14 Ibid., 60, 65-67.

15 H.J. Anslinger and C.R. Cooper (1937), "Marihuana: assassin of youth," American Magazine (July).

16 U.S. Senate, Committee on the Judiciary (1966), "Narcotic Rehabilitation Act of 1966," p. 459.

17 U.S. House of Representatives, Committee on Ways and Means (1937), "Taxation of Marihuana."

18 "Danger," Survey Graphic 27 (April, 1938): 37; H.G. Leach (1939), "One more peril for youth," Forum and Century 101 (January): 1-2.

19 "Marihuana more dangerous than heroin or cocaine," Scientific American 1.58 (May 1938): 293; "Marihuana," Journal of Home Economics 30 (1938): 477-479; G.R. McCormack (1937), "Marihuana," Hygeia 15: 898-899; "Marihuana smoking seen as epidemic among the idlc," Science News Letter 34 (1938): 340; M.A. Marshall (1939), "Marihuana," American Scholar 8 (1): 95-101; R. Adams (1940), "Marihuana," Science 92: 115-119.

20 G.R. McCormack (1937), op. cit.; E. and R. Rowell (1939), op. cit.

21 Scientific American (1938), op. cit.

22 E. Rowell and R. Rowell (1939), op. cit., 41.

23 N. Polsky (1967), Hustlers, Beats, and Others, Garden City, New York: Doubleday.

24 R.J. Bonnie and C. Whitebread II (1974), op. cit., 35-36; D. Musto (1973), op. cit., 330.

25 A.H. Lewis (1913), "Marihuana," Cosmopolitan 55: 645-655.

26 R.J. Bonnie and C. Whitebread II (1974), op. cit.; P. Morgan (1978), "The Political Uses of Moral Reform: California and Federal Drug Policy, 1910-1960," Ph.D. Dissertation, Department of Sociology, University of California, Santa Barbara.

27 D. Musto (1973), op. cit., 218-219.

28 New Orleans Times-Picayune, 17 October 1926.

29 A.E. Fossier (1931), "The marihuana menace," New Orleans Medical and Surgical Journal 84: 247-252; E. Stanley (1931), "Marihuana as a developer of criminals," Journal of Police Science 2: 256+; F. Gomila and M. Lambou (1938), "Present Status of the Marihuana Vice in the United States," pp. 27-39 in Robert P. Walton (ed.), Marihuana, Philadelphia: J.B. Lippincott.

30 U.S. National Commission on Law Observance and Enforcement (1931), "Report on Crime and the Foreign Born," p. 205.

31 R.J. Bonnie and C. Whitebread II (1974), op. cit.

32 Cited in D. Musto (1973), op. cit., 222.

33 FBN (1929), op. cit., 15; FBN (1936), op. cit.

34 McCormack (1937), op. cit.; Scientific American (1938), op. cit.; C.A. Brown (1938), "Marihuana," Nature 31 (May): 271-272; W. Gard (1938), "Youth gone loco," The Christian Century 55 (June 20): 812-813; Journal of Home Economics (1938), op. cit.; Leach (1938), op. cit.; S.R. Winters (1940), "Marihuana," Hygeia 18: 885-887. 
35 W. Wolf (1936), "Uncle Sam fights a new drug menace ... Marijuana," Popular Science Monthly" 128 (May): 14-15, 119-120; C.W. Beck (1938), "Marijuana menace," Literary Digest 125 (1 January): 26; Gard (1938), op. cit.

36 A. Parry (1935), "The menace of marihuana," The American Mercury 36: 487-490; "Marihuana menaces youth," Scientific American 154 (March, 1936): 150-151; Marshall (1939), op. cit.

37 U.S. House of Representatives, Committee on Ways and Means (1951), "Control of Narcotics, Marijuana, and Barbiturates," p. 40.

38 U.S. Senate, Committee on the Judiciary (1966), op. cit.; U.S. House of Representatives, Committee on Interstate and Foreign Commerce, Subcommittee on Public Health and Welfare (1968), "Increased Control Over Hallucinogens and Other Dangerous Drugs," pp. 101-103.

39 U.S. National Commission on Marihuana and Drug Abuse (1972), Marihuana: A Signal of Misunderstanding, p. 73; U.S. Senate, Committee on the Judiciary, Subcommittee to Investigate the Administration of the Internal Security Act and Other Internal Security Laws (1974), "Marihuana-Hashish Epidemic and Its Impact on United States Security."

40 "More controversy about pot," Time 97 (31 May 1971): 65.

41 U.S. National Commission on Marihuana and Drug Abuse (1972), op. cit., 86-87.

42 Cited in S.E. Grupp (1971), op. cit., 295.

43 U.S. House of Reprsentatives, Committec on Interstate and Foreign Commerce, Subcommittee on Public Health and Welfare (1968), op. cit., 158.

44 The passages included here are U.S. Senate, Committee on the Judiciary, Subcommittee to Investigate Juvenile Delinquency (1969), "Narcotic Legislation," pp. 501, 516, 530-537, 571-609; U.S. Senate, Committee on Labor and Public Welfare, Special Subcommittee on Alcoholism and Narcotics (1970), "Federal Drug Abuse and Drug Dependence Prevention, Treatment, and Rehabilitation Act of 1970," p. 143; U.S. Hlouse of Representatives, Commitiee on Interstate and Foreign Commerce, Subcommittee on Public Health and Welfare (1970), "Drug Abuse Control Amendments - 1970," pp. 180-181, 188, 551-554; U.S. House of Representatives, Committee on Ways and Means (1970), "Controlled Dangerous Substances, Narcotics, and Drug Control Laws," pp. 280 ff., 331-334, 449. They include testimony from the Department of Health, Education and Welfare; the House Select Committee on Crime; the National Congress of Parents and Teachers; the 1969 Presidential Task Force on Narcotics, Marihuana, and Dangerous Drugs; the director of the Harvard University Health Services; the National Association of Retail Druggists; and others.

45 U.S. House of Representatives, Committee on Ways and Means (1970), op. cit., 280.

46 U.S. House of Representatives, Committee on Interstate and Foreign Commerce, Subcommittee on Public Health and Welfare (1970), op. cit., 554.

47 U.S. National Commission on Marihiana and Drug Abuse (1972), op. cit., 86-87, 97, 99.

48 U.S. Senate, Committee on the Judiciary, Subcommittee to Investigate the Administration of the Internal Security Act and Other Internal Security Laws (1974), op. cit., 51, 193.

49 Ibid., 18-30, 206-250, 154-169.

50 Ibid., 206-250, 154-159.

51 U.S. House of Representatives, Select Committee on Crime (1969), "Crime in America - Drug Abuse and Criminal Justice," p. 172.

52 U.S. Senate, Committee on the Judiciary, Subcommittee to Investigate the Administration of the Internal Security Act and other Internal Security Laws (1974), op. cit., 214, 232.

53 These included the President's Ad Hoc Panel on Drug Abuse (1962), the White House Conference on Narcotic and Drug Abuse (1962), and the President's Advisory Commission on Narcotic and Drug Abuse (1963).

54 The carly drugs-on-campus, drugs-in-the-suburbs articles included R. Goldman (1964), "Dope invades the suburbs," Saturday Evening Post (April 4); "Narcotics: Slum to Suburb," Newsweek (22 February 1965); J. Larner (1965), "The college drug scene," The Atlantic Monthly (November); and Time (1965), op. cit.

55 G. Jaeger and P. Selznick (1964), "A normative theory of culture," American Sociological Review 29: 653-669. 
56 J. Hart (1972), "Marijuana and the counter culture," National Review 23: 1348.

57 U.S. National Commission of Marihuana and Drug Abuse (1972), op. cit., 167.

58 R. Brotman and F. Suffet (1973), "Marijuana Use: Values, Behavioral Definitions, and Social Control," pp. 1078-1110 in U.S. National Commission on Marihuana and Drug Abuse (ed.), Drug Use in America, Appendix I; L. Grinspoon (1971), Marihuana Reconsidered, New York: Bantam; J. Kaplan (1970), Marijuana - The New Prohibition, New York: World Publishing.

59 C. Geertz (1973), "Ideology as a Cultural System," pp. 193--233 in The Interpretation of Cultures, New York: Basic Books; G. Jaeger and P. Selznick (1964), op. cit. 